JURNAL PANGAN DAN GIZI Vol (No): 1-10, April 2020

ISSN (Online) : 2656-0291

Tersedia online di http://jurnal.unimus.ac.id/index.php/JPDG

\title{
ANALISA KELAYAKAN USAHA DISTRIBUTOR BUAH KELAPA DI BANGETAYU WETAN GENUK SEMARANG
}

\author{
Feasibility Analyse of Distributor Coconut in Bangetayu Wetan Genuk Semarang \\ Athfal Alex Al Buntoni 1), Muhammad Yusuf ${ }^{2)}$ \\ 1) Program Studi Teknologi Pangan Fakultas Ilmu Keperawatan dan Kesehatan Universitas \\ Muhammadiyah Semarang \\ ${ }^{2}$ Program Studi Teknologi Pangan Fakultas Ilmu Keperawatan dan Kesehatan Universitas \\ Muhammadiyah Semarang \\ Penulis korespondensi : email alex.albuntoni@gmail.com
}

\begin{abstract}
Potential coconut illustrated from of crop productivity in Central Java as the primary commodity reached 1.2864 million tons in 2015. Cashflow from research object coconut distributor reached Rp. 1.536.678.000/ years. The analyse of activity series composed by organisation structure, distribution plot, product handling. Product diversification, layout, and employe. Value of financial analyse carried out NPV (Net Present Value) 2.056.306.704, value of BC Ratio (Benefit Cost Ratio) 6,23, value of IRR (Internal Rate of Return) 40,16\%. This research, if NPV have positif, so haved affect to positif BC Ratio and IRR haved greater value from interest rate so that Musriah coconut bussines keeping worth. Value of payback periode is 0,88 , so to recoup only takes 10 month 21 days. Marketing mix contain of 4P with Product 3,69 and Price 3,87. Grade of product and price have a good criteria, cause consumer can fulfilled the expectation. Grade of place is 3,54 and grade of promotion is 3,15. Grade of place and promotion have a good criteria, but needed a repair to be better.
\end{abstract}

Key words; coconut, financial analyse, marketing mix. 


\section{PENDAHULUAN}

Menurut BPS Jawa Tengah (2015), Jawa Tengah memiliki sumbangsih untuk ekspor pada ketegori komoditi pertanian dan komoditi kehutanan sebesar 264.370,99 ton, sedangkan untuk produksi jenis tanaman di Jawa Tengah kelapa menjadi komiditi teratas dengan nilai 1.284.384,95 ton.

Kota Semarang merupakan Ibukota dari Provinsi Jawa Tengah, dimana semua kegiatan terpusat di kota ini tidak terkecuali kegiatan wirausaha kelapa. Peneliti tertarik dengan aktivitas wirausaha disepanjang Jl. Wolter Mangunsidi untuk komoditi kelapa muda. Potensi ini didukung dengan topografi daerah yang digunakan sebagai jalur keluar dan masuk arah Kota Semarang ke Jalan Patura (Pantai Utara) arah Kabupaten Demak atau sebaliknya.

\section{BAHAN DAN METODE}

Penelitian ini termasuk penelitian jenis observsi lapangan yang dengan mengkaji tentang analisa keyalakan usaha buah kelapa.

\section{Bahan}

Bahan yang digunakan dalam penelitian ini adalah data yang meliputi penyelenggaraan kegiatan dan data keuangan distributor buah kelapa.

\section{Alat}

Alat yang digunakan dalam penelitian adalah kuesioner sebagai alat pengambilan data penyelenggaraan rangkian kegiatan, analisa finansial dengan formulasi perhitungan NPV (Net Present Value), IRR (Internal Rate of Return), BCR (Benefit Cost Ratio), dan PP (Payback Periode) dan bauran pemasaran dengan formulasi $4 \mathrm{P}$ Product (produk), Price (harga), Place (tempat), dan Promotion (promosi).

\section{HASIL DAN PEMBAHASAN}

\section{Objek Penelitian}

Usaha Ibu Musriah merupakan salah satu usaha yang bergerak dalam penyalur hasil perkebunan yaitu buah kelapa. Industri ini beralamat di Desa Bangetayu Wetan RT 11 RW 04, Kecamatan Genuk, Kota Semarang, Jawa Tengah. Ibu Musriah sebagai pemilik perusahaan merintis sejak tahun 1993.

Kegiatan yang dilakukan masih tradisional tergambarkan dari struktur organisasi dimana Ibu Musriah sebagai pemimpin merangkap jabatan sebagai sekretaris dan bendara. Hal ini sesuai dengan Supriyanto (2012), organisasi tradisional adalah organisasi dipandang sebagai sebuah sistem tertutup dimana semua variabel diperhatikan dan berada dibawah pengendalian pihak manajemen atau pemimpin.

\section{Alur Distribusi}


Alur distribusi usaha kelapa Ibu Musriah berawal dari petani kelapa di Kebumen yang terdistribusikan ke pengepul dengan perantaran kotak langsung dan kuli panjat.

Kontak langsung merupakan kegiatan perantara pengepul ke pengecer ataupun konsumen. Sebagai distributor, Ibu Musriah memasarkan produknya di Bangetayu dan sekitar Semarang Timur. Sistem pemasaran yang dilakukan dengan cara melakukan pengiriman berdasarkan

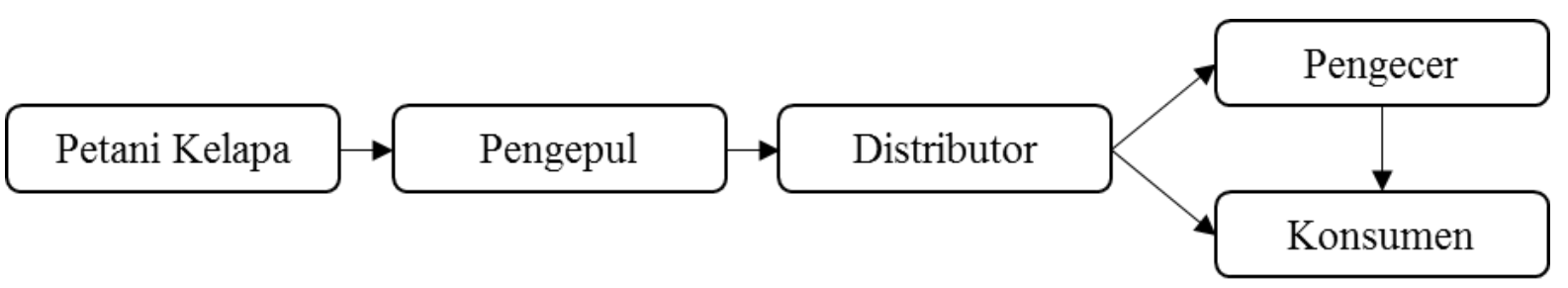

yang dilakukan oleh para petani kelapa permintaan ataupun pembeli dapat yang memetik kelapa kemudian mengkomunikasikan ke pengepul

untuk mengambil barang di kebun.Kuli Panjat merupakan kegiatan dilakukan oleh pengepul yan!

Gambar 1. Alur distribusi buah kelapa Ibu Musriah

langsung datang ke tempat Ibu Musriah. pohon kelapa untuk mencann puan kelapa pengepur uengan mengкоmunikasikan di petani kelapa kemudian disetor ke pengepul.

Distribusi merupakan bagian yang tidak terpisahkan dari rantai pasok suatu produk. Peran distribusi menentukan bagi tersampaikannya sebuah produk sampai ke tangan konsumen. Dibutuhkan suatu proses yang efisien, yang menjamin produk sampai ke tangan konsumen secara luas dengan biaya yang minimal (Prasetyo, 2008).

Ibu Musriah dalam rantai pasok ini bertindak sebagai distributor. Ibu Musriah merupakan pihak penyalur dan sebagai terlebih dahulu terkait kebutuhan. Pihak pengepul akan melakukan checking terkait dengan ketersediaan kelapa dan armada sebagi alat transportasi. Pihak distributor rata-rata mendapatkan supplay sebanyak 3 kali per minggu dengan kapasitas 5.400 butir per minggu dengan harga distributor Rp 4.500,-.

Pengecer langsung merupakan pengecer yang datang secara langsung dan memilih produk secara bebas pada display distributor. Pengecer tidak langsung merupakan pengecer mendapatkan supplay 
dari distributor dengan pengiriman langsung sesuai dengan kebutuhan.

Konsumen pada alur usaha ini mendapatkan produk dengan 2 cara yaitu dari distributor ataupun dari pengecer. Konsumen dari distributor Ibu Musriah memiliki persebaran di daerah Semarang Timur meliputi Mbugen, Kudu, Bajar Dowo, dan Nggasem.

\section{Proses Penangan Produk}

Proses pengiriman dari pengepul ke distributor menggunakan truk dengan kapasiatas 1.800 butir kelapa. Kelapa dimuat dalam bak truk kemudian bak ditutup dengan terpal dengan tujuan agar buah kelapa tetap terjaga kesegarannya. Pengiriman dilakukan pada malam hari dari Kebumen Pukul 22.00 dengan jarak tempuh 5 jam sehingga sampai Semarang Pukul 03.00 pada hari berikut.

Proses penurunan masih dilakukan secara tradisional yaitu dengan menurunkan satu per satu kelapa dikarenakan armada truk belum menggunakan truk versi piston sehingga bak dapat dinaikan ke atas dan kelapa dapat turun dari bak. Proses penurunan dilakukan oleh 2 orang pekerja dibantu oleh kenet dan sopir truk. Posisi penurunan 2 orang berada di atas dan 2 orang di bawah, sehingga 1 orang di bawah akan menerima turunan kelapa dari 1 orang di atas truk.
Proses penyortiran adalah proses untuk memilih dan mengklasifikasikan suatu produk berdasarkan kriteria yang telah ditetapkan. Cara pengecekan kelapa muda adalah dengan memukul kulit buah kelapa jika berbuyi padat "bleg" dan dikocokkocok tidak bunyi berarti itu kelapa muda. Kosumen kelapa muda ini adalah pedagang es kelapa muda atau individu. Pengecekan pada kelapa tua adalah dengan memukul kulit buah kelapa jika berbuyi ringan " $t a k$ " dan dikocok-kocok bunyi berarti itu kelapa tua. Konsumen kelapa tua ini adalah pedagang kelapa tua ataupun individu untuk kebutuhan pembuatan santan ataupun produk makanan seperti geplak sari. Sedangkan, pengecekan rusak adalah dengan melihat visual buah kelapa terdapat terusakan atau tidak dan paling utama pada tangkai dan tutup buah bagian atas busuk atau tidak.

Proses pengupasan adalah proses untuk mengupas kulit buah kelapa sehingga diperoleh buah kelapa yang terlihat tempurung. Proses kupas ini dilakukan pada buah kelapa tua saja dengan tujuan mempermudah konsumen untuk langsung memecah tempurung dan dapat mengambil daging buah kelapa.

Pengiriman dilakukan dengan armada dari distributor yaitu mobil pick up. Proses pengiriman ini memiliki batas minimal pemesanan yaitu 150 butir atau total area 
pengiriman setempat minimal 150 butir. Hal ini dilakukan untuk menutup biaya pengiriman terutama bahan bakar.

\section{Spesifikasi Produk}

Usaha Ibu Musriah ini memberikan beberapa pilihan produk bagi konsumen dengan harga semua varian Rp 5.500,-. Harga ini dapat berubah sesuai dengan harga dari pengepul namun margin keuntungan yang ditetapkan sama yaitu $\mathrm{Rp}$ $1.000,-$.

Tabel 1. Diversifikasi produk

\begin{tabular}{cll}
\hline No & Nama Produk & Tujuan Konsumsi \\
\hline 1 & Kelapa Muda & \\
& a. Cengkir & Pengobatan \\
& b. Padat & Pembuatan produk \\
& & \\
2 & Kelap Tua & \\
& a. Kupas & Pembuatan santan \\
& b. Utuh & Pembuatan santan \\
\hline
\end{tabular}

\section{Layout Kerja}

Layout kerja diposisikan pada halaman rumah distributor dengan lantai paving dan beratap asbes. Kelapa muda memiliki tempat tersendiri dalam penyimpanan. Tempat sortir merupakan tempat untuk menurunkan material dari truk pengiriman. Tempat kelapa kupas merupakan temapat fleksibel dapat juga sebagai tempat parkir kendaran saat menurunkan material. Setelah penurunan selesai, barulah fungsional tempat kelapa kupas berjalan.
Tempat parkir armada merupakan tempat yang digunakan armada pick up distributor untuk melakukan pengiriman ke pengecer. Tempat limbah ini digunakan untuk limbah kulit kelapa dari kelapa tua yang dikupas dan kelapa yang rusak.

\section{Tenaga Kerja}

Ibu Musriah memiliki 3 pekerja utama yaitu pada bagian pengadaan material, pengolahan material, dan pengiriman produk. Pekerja memiliki jam kerja dari Pukul 03.00 - 11.00 atau 8 jam kerja. Upah yang diterima tiap pekerja yaitu Rp 50.000,-. Pekerjaan lembur pada proses pengupasan kelapa diberi upah $\mathrm{Rp}$ 100,- per kelapa. Pada proses pengupasan, jika kelapa tua melimpah maka diperbantukan tenaga tambahan dengan upah yang sama yaitu Rp 100,- per kelapa. Semua tenaga kerja berasal dari lingkungan sekitar dengan tujuan memberikan lapangan kerja bagi lingkungan sekitar.

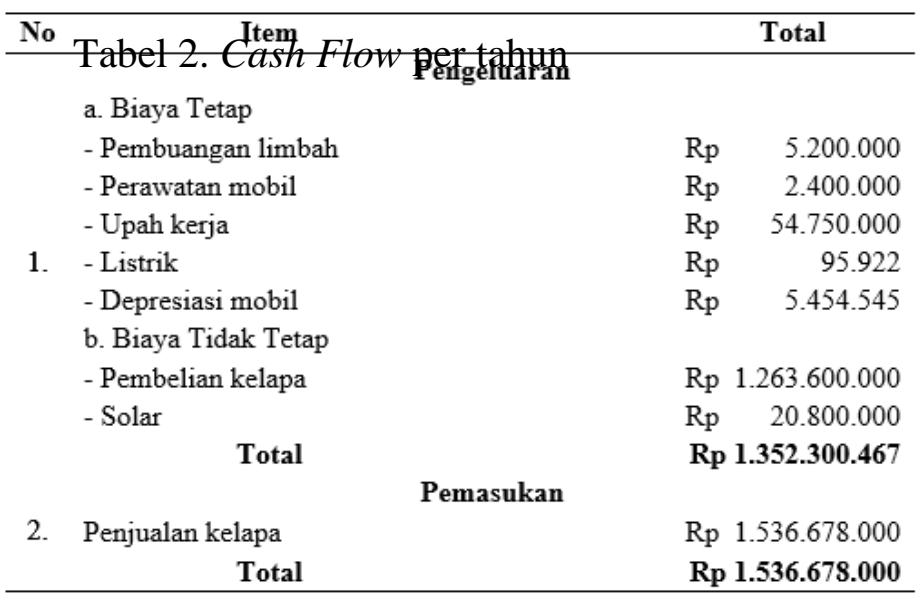

Analisa Finansial 
Analiasa finansial didasarkan pada data keuangan usaha Ibu Musriah. Peneliti terbantu dengan sikap positif distributor ini sebagai objek penelitian karena sikap keterbukaan akan data keuangan. Cash Flow per tahun wirausaha Ibu Musriah ditunjukan pada Tabel 2.

Analisa finansial merupakan salah satu aspek dalam kegiatan wirausaha. Pengeluaran dan pemasukan menjadi dasar dalam analisa finansial dengan beberapa metode yaitu NPV (Net Present Value), BC Ratio (Benefit Cost Ratio), IRR (Internal Rate of Return), dan PP (Payback Periode). Tujuan dari penggunaan metode ini adalah untuk mengetahui kelayakan suatu usaha untuk dipertahankan atau tidak dan analisa waktu yang dibutuhkan suatu
Rustiadi et all (2011), nilai bersih sekarang akan menggambarkan keuntungan dan layak dilaksanakan jika mempunyai nilai positif. Disisi lain, analisa NPV di atas menggambar usaha tersebut menguntungkan secara berkala dikarenakan nilainya yang positif.

Usaha kelapa Ibu Musriah memiliki kondisi penerimaan tahun pertama $\mathrm{Rp}$ 1.536.678.000 dan keuntungan tiap tahun Rp 184.377.533 sehingga diperoleh nilai BC Ratio diperoleh 6,23. Dengan nilai BC Ratio > 0 maka usaha buah kelapa dinyatakan layak untuk dipertahankan yang sesuai dengan Zacoeb (2014), jika nilai $\mathrm{BCR} \geq 1$ maka investasi layak dipertahankan.

Tabel 3. Analisa finansial usaha kelapa Ibu Musriah

\begin{tabular}{|c|c|c|c|}
\hline No & Analisa Finansial & Nilai & Ket. \\
\hline 1. & NPV & 2.056 .306 .704 & Nilai > 0, layak dipertahankan \\
\hline 2. & BC Ratio & 6,23 & Nilai > 0, layak dipertahankan \\
\hline 3. & IRR & $40,16 \%$ & Nilai $>6 \%$, layak dipertahankan \\
\hline 4. & $\mathrm{PP}$ & 0,88 & Mendekati 0 , lebih baik \\
\hline
\end{tabular}

usaha untuk balik modal.

Nilai NPV diperoleh 2.056.306.704, nilai tersebut menggambar bahwa arus khas yang diperkirakan pada 5 tahun kedepan adalah senilai 2.056.306.704 perhitungan saat ini dengan suku bunga $6 \%$. Dengan nilai NPV > 0 mengartikan bahwa usaha buah kelapa dinyatakan layak untuk dipertahankan. Hal ini sesuai dengan
Kedua analisa yaitu NPV dan BC Ratio memiliki hubungan dengan kriteria yang digunakan adalah jika BCR > 1 berarti NPV > 0 dan memberikan tanda "layak" untuk suatu usulan kegiatan (Tarigan, 2010). Dengan demikian, hasil penelitian ini memperkuat hasil penelitian Tarigan karena analisa usaha Ibu Musriah 
menghasilkan nilai BC Ratio > 1 ketika nilai NPV $>0$.

Nilai IRR diperoleh 40,16\%, dengan kondisi trail nilai discount rate $\mathrm{P} / \mathrm{A}$ pada $10 \%, 35 \%, 40 \%$ dan $45 \%$ diketahui nilai yang mendekati 0 pada discount rate $40 \%$ dan $45 \%$ sehingga diperoleh $30.68 \%$. Menurut Rustiadi et all (2011), jika nilai IRR lebih kecil dengan nilai suku bunga (i) yang berlaku sebagai social discount rate, maka NPV usaha atau industri besarnya nol (negatif) artinya usaha atau industri sebaiknya tidak dilaksanakan. Hasil penelitian pada distributor Ibu Musriah selaras dengan penelitian di atas pada nilai yang berkebalikan karena nilai IRR $40,16 \%>$ suku bunga $6 \%$ dan nilai NPV > 0 sehingga usaha Ibu Musriah layak untuk dipertahankan.

Menurut Dewi dan Yadnya (2013), jika analisa Payback Periode lebih pendek waktunya dibandingkan waktu yang ditentukan maka invetasi layak dipertahankan. Nilai 0,88 jika dikonversi dalam bulan adalah 10 bulan 21 hari, hasil penelitian ini memenuhi kriteria di atas yaitu lebih pendek $(<5)$ tahun dikarenakan masa analisa yang dilakukan pada penelitian ini adalah kurun waktu 5 tahun atau mendekati nol (0) sehingga usaha kelapa Ibu Musriah layak dipertahankan.

\section{Analisa Bauran Pemasaran}

Bauran pemasaran terdiri Product, Place, Price, dan Promotion atau 4P merupakan metode yang digunakan untuk menganalisa kelayakan usaha (Kotler, 2008). Pendekatan yang dilakukan adalah dengan membuat kuesioner dengan detail kriteria-kriteria yang dapat menjadi tolak ukur terhadap respon masyarakat berdasarkan aspek pokok di atas.

Metode riset pasar terhadap responden menjadi fokus penelitian ini dengan melakukan skoring dari nilai 1-4 dengan kriteria 1 (sangat buruk), 2 (buruk), 3 (baik), dan 4 (sangat baik). Responden berasal dari pengecer, konsumen, dan warga sekitar tempat usaha.

Tabel 4. Analisa Bauran Pemasaran Ibu Musriah

\begin{tabular}{|c|c|c|c|c|c|c|c|}
\hline No. & PERNYATAAN & 1 & 2 & 3 & 4 & $\mathbf{N}$ & $\Sigma$ \\
\hline \multirow{4}{*}{3} & \multicolumn{7}{|l|}{ Tempat } \\
\hline & a. Strategis & & & 4 & 26 & 30 & 116 \\
\hline & b. Kebersihan & & & 21 & 9 & 30 & 99 \\
\hline & c. Layout tempat penjualan & & & 16 & 14 & 30 & 104 \\
\hline
\end{tabular}

Maka nilai place diperoleh dengan:

$$
\begin{aligned}
\text { Place } & =\frac{\sum(3 a, 3 b, 3 c)}{n(3 a, 3 b, 3 c)} \\
& =\left(\frac{116+99+104}{30+30+30}\right)=\mathbf{3 . 5 4}
\end{aligned}
$$


Total jumlah nilai untuk tiap skoring 14 dibagi dengan 30 sebagai total koresponden. Kemudian, nilai pada masing-masing aspek 4P dicari rata-rata yang selanjutnya menjadi nilai analisa pada kategori Product, Place, Price, dan Promotion. Simulasi analisa ini ditunjukan pada Tabel 9 untuk kategori Place (tempat).

menjaga kualitas produk dan pelayanan yang menjadi faktor pendorong kepuasan pelanggan. Dengan demikian usaha Ibu Musriah sudah memuaskan karena untuk nilai kategori produk memiliki nilai 3,69 dengan kriteria sangat baik.

Analisa harga meliputi harga jual, keterjangkauan, dan kesesuai harga dengan kualitas. Hasil pada Tabel 10 untuk kategori harga memiliki nilai 3,87 jika dibulatkan menjadi 4 yang termasuk pada kriteria sangat baik. Kategori harga juga menjadi nilai keunggulan dari usaha Ibu Musriah. Harga yang ditawarkan Ibu Musriah adalah Rp 5.500,-.

Tabel 3. Perhitungan survei kategori tempat (Place)

\begin{tabular}{clcc}
\hline No & Analisa Pemasaran & Hasil Analisa & Keterangan Pembulatan \\
\hline 1. & Product (Produk) & 3,69 & Sangat Baik \\
3. & Price (Harga) & 3,87 & Sangat Baik \\
2. & Place (Tempat) & 3,54 & Baik \\
4. & Promotion (Promosi) & 3,15 & Baik \\
\hline
\end{tabular}

Analisa produk meliputi kualitas kelapa muda dan tua serta pelayanan terhadap konsumen. Hasil pada Tabel 10 untuk kategori produk memiliki nilai 3,69 jika dibulatkan menjadi 4 yang termasuk pada kriteria sangat baik. Dengan kriteria sangat baik maka analisa produk menjadi nilai keunggulan dari usaha Ibu Musriah. Hal ini menggambarkan bahwa aspek kualitas produk dan cara pelayan terhadap konsumen sudah sangat baik. Menurut Aditia dan Suhaji (2012), perusahaan harus
Hasil ini dapat menggambarkan Ibu Musriah telah menjaga tingkat loyalitas konsumen. Hal ini memperkuat penelitian yang dilakukan Aditia dan Suhaji (2012), peningkatan harga tidak akan mempengaruhi kepuasan pelanggan jika konsumen sudah loyal.

Analisa tempat meliputi kestrategisan, sanitasi, dan layout kerja. Hasil pada Tabel 10 untuk kategori tempat memiliki nilai 3,54 jika dibulatkan menjadi 3 yang 
termasuk pada kriteri baik. Aspek sanitasi yang perlu diperhatikan adalah tempat display produk masih terkontak langsung dengan paving sehingga monitoring terhadap debu kurang terjaga. Disisi lain, diperlukan alas seperti palet untuk tempat display produk sehingga tidak kontak langsung terhadap tanah. Menurut Permentan No 35 (2008), bangunan untuk produk agro harus mudah dibersihkan, mudah disanitasi atau didesinfektasi. Dengan demikian, diperlukan perbaikan sanitasi pada usaha Ibu Musriah dikarena minim monitoring terhadap debu.

Analisa promosi meliputi sumber konsumen mengenal produk dan teknik promosi. Hasil pada Tabel 10 untuk kategori promosi memiliki nilai 3,15 jika dibulatkan menjadi 3 yang termasuk pada kriteri baik. Identifikasi terhadap aspek promosi adalah promosi dinilai kurang menarik. Promosi yang dilakukan Ibu Musriah yaitu promosi hanya dari mulut ke mulut. Disamping itu, masih terdapat kekurangan pada aspek promosi visual. Hal ini dapat dianalisa dari tidak adanya atribut visual seperti sapanduk, stiker, leflet dan lain sebagainya di tempat usaha. Kelemahan ini harus menjadi fokus usaha ini. Promosi visual dapat dijadikan tanda pengenal dan menarik perhatian konsumen sehingga diharapkan dapat meningkatkan penjualan. Hal ini memperkuat penelitian
Sunarya dan Assyifa (2015), media visual sangat besar pengaruhnya terhadap penyampaian informasi yang dibutuhkan oleh masyarakat.

\section{KESIMPULAN DAN SARAN}

Potensi usaha kelapa Ibu Musriah didukung dengan kelimpahan komoditi mencapai 1.286.400 ton dan tempat yang strategis dekat main road Pantura (Patai Utara) memberikan keuntungan bagi pelaku usaha. Hal ini juga didukung dengan kegiatan yang komplek meliputi alur distribusi, sistem pemasaran, tenaga kerja, proses penangan material, dan diversifikasi produk.

Analisa finansial dari usaha kelapa Ibu Musriah memiliki nilai NPV sebesar 2.056.306.704,-, BC Ratio 6,23, dan IRR 40,16\% sehingga ada hubungan jika NPV bernilai positif maka BC Ratio akan bernilai positif dan IRR bernilai lebih besar dari suku bunga. Hasil tersebut menyatakan bahwa usaha Ibu Musriah layak dipertahankan dengan diperkuat dengan nilai PP 0,88 sehingga hanya diperlukan waktu kurang dari 1 tahun untuk mengembalikan modal.

Analisa bauran pemasaran menggunakan skroring 1-4 dengan nilai pembulatan berdasarkan kriteria 1(sangat buruk), 2 (buruk), 3 (baik), dan 4 (sangat baik). Nilai kategori Product (produk) 3,69 dan Price (harga) 3,87 sehingga 
termasuk kriteria sangat baik dan menjadi keunggulan dari usaha Ibu Musriah, sedangkan untuk Place (tempat) 3,54 dan Promotion (promosi) 3,15 termasuk kriteria baik.

Pada aspek promotion sebaiknya dilakukan pengembangan dengan membuat berbagai media promotion visual seperti spanduk, leflet, atau stiker sehingga lebih menarik konsumen. Sedangkan, aspek place sebaiknya dilakukan pengembangan untuk pembuatan alas untuk buah kelapa sehingga terjaga dari kontak langsung dengan tanah atau lantai.

\section{DAFTAR PUSTAKA}

Aditia, Indra dan Suhaji. 2012. FaktorFaktor yang Mempengaruhi Kepuasan Pelanggan pada UD Panda Wangi Semarang. Jurnal Widya Manggala

Badan Pusat Statistika. 2015. Jawa Tengah Dalam Angka. Dinas Perkebunan Provinsi Jawa Tengah.

Dewi, Ni Luh P. M. K. dan I P. Yadnya. 2013. Studi Kelayakan Invetasi dari Aspek Finansial untuk Pendirian Naya Salon Depansar. Jurnal Portal Garuda, Jurnal Online Portal GaruDA. Hal 32-50.

Kotler, P. 2008. Manajemen Pemasaran. Prenhallindo. Jakarta

Permentan. 2008. Persyaratan dan Penerapan Cara Pengolahan Hasil
Pertanian Asal Tumbuhan yang Baik (Good Manufacturing Practices). Peraturan Menteri Pertanian No. 35.

Prasetyo, B. Suseno. 2008. Analisa Efisiensi Distribusi Pemasaran Produk dengan Metode Data Envelopment Analysis (DEA). Jurnal Peneletian Ilmu Teknik Vol. 8, No. 2, Hal. 120-128.

Rustiadi, E., Susun S. dan Dyah R. 2011. Perencanaan dan Pengembangan Wilayah. Yayasan Pustaka Obor Rakyat, Jakarta.

Sunarya, L. Po, A. Sunarya, J.D. Assyifa. 2015. Keefektifan Media Komunikasi Visual sebagai Penunjang Promosi pada Perguruan Tinggi Raharja. Jurnal Raharja, Vol. 9, No. 1, Hal 77-86.

Supriyanto, M. 2012. Konsep Manajemen dan Kepemimpinan Islam dalam Perusahaan. Jurnal Bandung Islam, Vol. 10, No. 2, Hal 7-32.

Zacoeb, A. 2014. Benefit Cost Ratio. Universitas Brawijaya. Malang. 